\title{
The priesthood of believers: The forgotten legacy of the reformation
}

\begin{tabular}{|c|c|}
\hline $\begin{array}{l}\text { Author: } \\
\text { Wim A. Dreye }\end{array}$ & \\
\hline $\begin{array}{l}\text { Affiliations: } \\
{ }^{1} \text { Department } \\
\text { and Historical } \\
\text { Faculty of The } \\
\text { Religion, Univ } \\
\text { Pretoria, Pret } \\
\text { South Africa }\end{array}$ & $\begin{array}{l}\text { of Systematic } \\
\text { Theology, } \\
\text { ology and } \\
\text { ersity of } \\
\text { oria, }\end{array}$ \\
\hline $\begin{array}{l}{ }^{2} \text { Centre for Re } \\
\text { Theology, Her } \\
\text { Teologiese Ko } \\
\text { South Africa }\end{array}$ & $\begin{array}{l}\text { formed } \\
\text { vormde } \\
\text { lege, Pretoria, }\end{array}$ \\
\hline $\begin{array}{l}\text { Research Proj } \\
\text { Project Leade } \\
\text { Project Numb }\end{array}$ & $\begin{array}{l}\text { ect Registration: } \\
\text { r: Wim Dreyer } \\
\text { er: } 77370920\end{array}$ \\
\hline $\begin{array}{l}\text { Description: } \\
\text { This research } \\
\text { project, 'Justi } \\
\text { Dignity. A Ref } \\
\text { perspective', } \\
\text { Wim Dreyer, } \\
\text { Church Histor } \\
\text { Polity, Faculty } \\
\text { University of }\end{array}$ & $\begin{array}{l}\text { is part of the } \\
\text { e and Human } \\
\text { ormed } \\
\text { lirected by Dr } \\
\text { epartment of } \\
\text { y and Church } \\
\text { of Theology, } \\
\text { retoria. }\end{array}$ \\
\hline $\begin{array}{l}\text { Correspondin } \\
\text { Wim A. Dreye } \\
\text { wim.dreyer@ }\end{array}$ & $\begin{array}{l}\text { g author: } \\
\text { r, } \\
\text { up.ac.za }\end{array}$ \\
\hline $\begin{array}{l}\text { Dates: } \\
\text { Received: } 03 \\
\text { Accepted: } 11 \\
\text { Published: } 19\end{array}$ & $\begin{array}{l}\text { pr. } 2020 \\
\text { Aug. } 2020 \\
\text { Oct. } 2020\end{array}$ \\
\hline $\begin{array}{l}\text { How to cite th } \\
\text { Dreyer, W.A., } \\
\text { priesthood of } \\
\text { forgotten lega } \\
\text { reformation', } \\
\text { Studies/Theol } \\
76(4), \text { a6021. } \\
\text { org/10.4102/ }\end{array}$ & $\begin{array}{l}\text { is article: } \\
\text { 2020, 'The } \\
\text { believers: The } \\
\text { cy of the } \\
\text { HTS Teologiese } \\
\text { ggical Studies } \\
\text { https://doi. } \\
\text { its.v76i4.6021 }\end{array}$ \\
\hline $\begin{array}{l}\text { Copyright: } \\
\text { (c 2020. The } \\
\text { Licensee: AOS } \\
\text { is licensed un } \\
\text { Creative Comr } \\
\text { Attribution Lio }\end{array}$ & $\begin{array}{l}\text { uthors. } \\
\text { IS. This work } \\
\text { der the } \\
\text { nons } \\
\text { ense. }\end{array}$ \\
\hline Read online: & \\
\hline 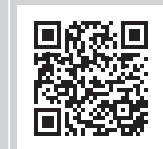 & $\begin{array}{l}\text { Scan this QR } \\
\text { code with your } \\
\text { smart phone or } \\
\text { mobile device } \\
\text { to read online. }\end{array}$ \\
\hline
\end{tabular}

Author:

Affiliations:

${ }^{1}$ Department of Systematic Religion, University of Pretoria, Pretoria,

${ }^{2}$ Centre for Reformed Theology, Hervormde Teologiese Kollege, Pretoria, Research Project Registration: Project Leader: Wim Dreyer Description:

This research is part of the Dignity. A Reformed perspective', directed by Dr Wim Dreyer, Department of Polity, Faculty of Theology, University of Pretoria.

Corresponding author: Wim A. Dreyer,

Dates:

Received: 03 Apr. 2020 Accepted: 11 Aug. 2020

How to cite this article: Dreyer, W.A., 2020, 'The priesthood of believers: The forgotten legacy of the reformation', HTS Teologiese Studies/Theological Studies 76(4), a6021. https://doi.

Copyright:

Licensee: AOSIS. This work

is licensed under the

Creative Commons

Attribution License.

mobile device
This contribution revisits the priesthood of believers. It is placed within the current discourse on relevant ecclesiologies and ecclesial praxis for 21st-century reformed churches. Luther placed much emphasis on the priesthood of believers in his rejection of the Roman Catholic differentiation between ordained clergy and laity. This was taken up by Calvin, but not to the same extent as Luther. The limited attention given to the priesthood of believers in reformed ecclesiologies, confessions and church orders is challenged in the current discourse on ecclesiology, especially by theologians working in the field of missional ecclesiology. Much emphasis is placed on the role of the 'ordinary' church member in terms of ministry. It is proposed that a continued reformation of the church would inter alia imply a renewed appreciation of the priesthood of believers. The shift in ecclesiology must be visible in reformed church polity and church orders. The interrelatedness of ecclesiology, church polity, church order and ecclesial praxis makes this unavoidable. A church order should not be regarded as an immutable historical document with everlasting authority, but rather as an instrument that could facilitate change and ecclesial praxis in the spirit of ecclesia semper reformanda. As such, church polity could even be regarded as a 'practical ecclesiology'. Recent changes to the Church Order of the Nederduitsch Hervormde Kerk van Afrika are used as a case study and to illustrate the point.

Contribution: The primary contribution of this manuscript contributes to the historical and systematic analysis of the concept 'priesthood of all believers', as well as its relevance to the current discourse on missional ecclesiology. It falls within the scope of HTS Theological Studies in terms of original theological research.

Keywords: reformed church polity; ecclesiology; priesthood of believers; Luther; Calvin; Van Ruler; Kraemer; Nederduitsch Hervormde Kerk van Afrika.

\section{Introduction}

The priesthood of believers was a cornerstone of Luther's understanding of the church. In Calvin's Institutes, it is mentioned several times. However, it has become a forgotten part of reformed ecclesiologies (Barth 1990:15) and more or less disappeared from the church orders of most reformed churches. In the current debate on missional ecclesiology, the priesthood of believers re-emerged as a central question (see Roldán 2004; Van Aarde 2017), although not uncontested (Voss 2013:vii). This contribution argues that the priesthood of believers should receive more and very specific attention in contemporary discourse on reformed ecclesiology, church polity, church orders and ecclesial praxis. Recent changes to the Church Order of the Nederduitsch Hervormde Kerk van Afrika (NHKA 2016) ${ }^{1}$ are used as a case study to illustrate the importance of the priesthood of believers.

There are several reasons why the priesthood of believers disappeared from reformed vocabulary. One important reason for this was the proliferation of churches and sects during the 16th century. Many of the sects had leaders who claimed to have special gifts, divine knowledge through the Holy Spirit and no need of formal theological education. They were regarded with suspicion and sometimes ruthlessly persecuted, martyred and ridiculed. Some Anabaptist leaders, like Baltazar Hübmaier, were highly educated theologians who differed substantially from Roman Catholic as well as Lutheran doctrine. Hübmaier was burned at the stake in Vienna in 1528.

The Anabaptists were convinced that every church member has the same rights and privileges as ordained clergy (Jones 1918:230). The fear of sectarianism and the opposition to Anabaptist views were probably the reason why the magisterial reformers became more restrained towards the 1.NHKA, Nederduitsch Hervormde Kerk van Afrika, is one of the Dutch Reformed churches in South Africa. 
priesthood of believers. This is already evident in the early writings of Luther (see Barth 1990:48). It led to a dichotomous approach, where the priesthood of believers was supported in theory but not in practice.

The neglect of the priesthood of believers in reformed circles (in theory it is somewhat different in the Roman Catholic Church after Vatican II) is quite evident in many major publications on ecclesiology. Two examples will suffice. In the 539 pages of the magisterial ecclesiology of Van't Spijker (ed. 1990) under the title De kerk - wezen, weg en werk van de kerk naar reformatorische opvatting, the priesthood of believers is never discussed. In the comprehensive Routledge Companion to the Christian Church (Mannion \& Mudge 2010), the priesthood of believers is mentioned on 3 of 684 pages, but never in connection with reformed ecclesiology or reformed church polity.

Over time, I believe, the neglect of priesthood of believers had a detrimental effect on reformed churches. It contributed to a strong institutional and structured ecclesiology in which the office of the minister became a dominant factor. More than often, the ministerial office limited growth instead of promoting it.

\section{Historical overview}

The priesthood of believers could be regarded as one of the central principles of the 16th-century Reformation. The doctrine asserts that all believers have equal access to God through Christ, the only high priest, and thus do not need any other priestly mediator. The implication of this doctrine is that all Christians are equal before God. Ordained clergy differ from non-ordained believers only in terms of function (ministerium) and not in terms of status (officium).

It is accepted by most scholars (see Voss 2013:149-152 for an overview) that the priesthood of believers was the obvious and almost uncontested way early Christianity functioned. In fact, early Christianity functioned primarily as a religious movement rather than a well-organised structure (see Dreyer 2016:68-136; Stark 1996; Van Aarde1995:632-633). That being said, it is also clear that the initial movement towards a formalised clergy is present in the New Testament. The 'offices' in the New Testament is so diverse that it is almost impossible to put it into an orderly system (see 1 Cor 12-14, Rm 12:6-8, Gl 6:6; 1 Th 5:12 en Phlp 1:1).

The diversity is evident within the same corpus. In the Pauline literature, one finds reference to apostles, prophets and teachers (1 Cor 12:28), as well as preaching, diaconate, teaching, support, leadership and support ( $\mathrm{Rm} \mathrm{12:6-8).} \mathrm{It} \mathrm{is}$ also clear that 'prophecy' (preaching the gospel) is more important than the other. It is possible that texts like Galatians 6:6, 1 Thessalonians 5:12 and Philippians 1:1 give some indication of the existence of a primitive form of office. On the other hand, there is the opinion that it does not indicate the existence of 'offices' at all, but rather gifts of the Holy
Spirit, which is more indicative of the general priesthood of believers. It is only in later New Testament material, especially the Pastoral Letters, where the charisma seems to be regulated and organised, even ordained by the laying of hands (see $1 \mathrm{Tm}$ 4:4-14; $2 \mathrm{Tm} \mathrm{1:6).} \mathrm{In} \mathrm{those} \mathrm{passages,} \mathrm{the}$ episkopos and presbuteros meet and even form a council. In summary, the New Testament presents us with a diverse form of ministry, including informal and formal ministry. The work had to be carried out, whether by 'ordained' or 'lay' people (to use contemporary language). Serving Christ was not about an important, formal position but rather a practical expression of discipleship.

As is clear from the Pastoral Letters, the institutionalisation of the offices began quite early. The process of institutionalisation is evident in the writings of Clement of Rome. Around AD 96, Clement of Rome sent a letter to church in Corinth, in which he distinguishes very clearly between the laypersons and priests. The First Letter of Clement to the Corinthians (see Goold \& Lake 1975) deals with ministry in the early church, the orderly succession or appointment of bishops, deacons and presbyters, as well as the respect with which they must be regarded. As such, it could be regarded as an early attempt to order ecclesial ministry and distinguish between ordained and non-ordained church members (see Moriarty 2012). We read, for instance (First Letter of Clement to the Cor, ch. 40):

$[F]$ or to the high priest the proper services ( $\left.\lambda \varepsilon \imath \tau o v \rho \gamma i \alpha_{1}\right)$ have been given, and to the priests the proper office has been assigned, and

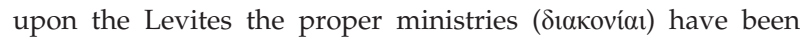

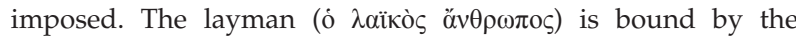

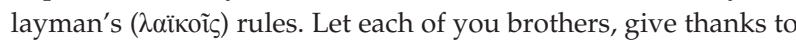
God with your own group ( $\left.\alpha^{\prime} \gamma \mu \alpha \tau\right)$, maintaining a good conscience, not overstepping the designated rule of his ministry

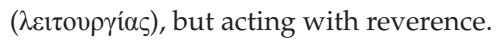

During the 3rd century, Cyprian was instrumental in the sacralisation of the ecclesial offices (Voss 2013:148). Cyprian's sacralisation of the clergy is a 'watershed', a 'new era' and 'major turning point' in the history of the doctrine of the priesthood of all Christians (Voss 2013:167). It is typified by Cyprian's view that only the bishop is worthy to enter the holy presence of God and bring sacrifices to God.

The institutionalisation of the Christian churches increased dramatically after the Edict of Milan (313 CE) and the Council of Nicaea (325 CE). This reflects in the writings of Eusebius and several other early Christian authors and theologians. Emperor Constantine became the Pontifex Maximus, the preeminent royal priest and 'bridge-builder' (pontifex) between God and man. Together with the sacralisation of the bishop, it resulted in 'defrocking' ordinary Christians. They were no longer priests responsible for ministry, but dependent on ordained clergy for their spiritual well-being. Tertullian's view that baptism is the ordination of every Christian to be a priest in service of Christ gradually disappeared. By the 5th century $\mathrm{CE}$, it was gone.

By the time the work of Pseudo-Dionysius (485-528 CE) appeared, the 'hierarchical access to God' was well established 
(Voss 2013:158). According to this view, God interacts with the world only through 'three levels' of clergy (bishop, priest and deacon). Only the bishop can stand in the place of Christ to offer to God what is required by God. The impact of his views cannot be underestimated. For instance, Thomas Aquinas cited Pseudo-Dionysius more than a 1000 times including his hierarchical views (Voss 2013:159).

The one voice speaking against this trend was that of Aurelius Augustine (354-430 CE). He maintained (infant) baptism as an ordination into Christ's royal priesthood. In his exposition of 1 Peter 2:9, he writes 'we call them all priests insomuch as they are members of the One Priest'. The responsibility of all those who were baptised is to offer their lives to God. Augustine defines the royal priesthood's 'true sacrifices' as 'works of mercy done to ourselves or our neighbour and directed to God' (see Voss 2013:175).

Following Augustine, the priesthood of believers became a cornerstone of the ecclesiology of Martin Luther and his rejection of the Roman Catholic exclusivist understanding of priesthood (Pont 1989:452). According to Luther, every Christian is someone else's priest, and we are all priests to one another. Luther based this view on two pillars, that is, the priesthood of Christ and his understanding of baptism. In such a way Luther demolished the distinction between clergy and laity. His ecclesiology was determined by his understanding of the church as a community of saints governed by the law of the priesthood of all believers. The priesthood of believers became the new law of the church's life (Althaus \& Schultz 1966:313). The church is founded upon the priesthood of Christ, and its structure is the priesthood of Christians (Aguilan 2015:3). The implications for church polity are self-evident. At the Council of Trent (1545-1563), Luther's views were rejected as could be expected in the light of the importance attached to the bishop as a mediator between God and man.

Luther articulated this understanding of the priesthood of believers in his 'Letter to the Christian Nobility' when he writes (Luther [1520] 1966):

$[I] \mathrm{t}$ is pure invention that pope, bishop, priests, and monks are called the spiritual estate while princes, lords, artisans, and farmers are called the temporal estate. This is indeed a piece of deceit and hypocrisy. Yet no one need to be intimidated by it, and for this reason: all Christians are truly of the spiritual estate, and there is no difference among them except that of office. Paul says in 1 Corinthians 12 that we are all one body, yet every member has its own work by which it serves the others. This is because we all have one baptism, one gospel, one faith, and are all Christians alike ... We are all consecrated priests through baptism ... It follows from this argument that there is no true, basic difference between laymen and priests, princes and bishops, between religious and secular, except for the sake of office and work, but not for the sake of status ... The priesthood of believers means that we stand before God, pray for others, intercede with and sacrifice ourselves to God and proclaim the Word to one another. (pp. 127-129)
The priesthood of believers was not so prominent in the theology of John Calvin (Niesel 1957:202). In Calvin's Institutes, the priesthood of believers is mentioned only in passing, almost as an afterthought when other issues are discussed. In the section (Inst. II/11/15) where Calvin explains the munus triplex, we find a cursory reference to the priesthood of believers (Inst. II/15/6), stating that although we are unclean, in Christ we are priests who can enter the heavenly sanctuary without fear, knowing that our prayers are acceptable to God.

The priesthood of believers is mentioned by Calvin (e.g. Inst. II/7/1) as an extension of Christ's priesthood. Calvin also mentions the priesthood of believers when he speaks about Peter and the keys of the kingdom (Inst. III/4/14 and again in IV/7/4 as well as IV/19/28). It is remarkable that Calvin does not discuss the priesthood of the believers in detail, never connects it to any ecclesial office (including the elders and deacons) and places it within the everyday life of the Christian (see Pont 1989:453).

Calvin emphasises that Christ is the only priest. That would lead to the logical conclusion that not only is the Roman Catholic Church in error by maintaining the priestly office, but a 'general priesthood' in Reformed churches would also be suspect. As a result, in the Reformed tradition, there is a very strong emphasis on ordained ministry, as well as an underestimation of the priesthood of believers. The role of the 'ordinary' church member is articulated in terms of 'calling' and everyday life, whilst the ordained minister, elder and deacon have clearly defined responsibilities, the one not allowed to transgress onto the other's responsibilities. It is, for instance, not allowed to serve simultaneously in the various offices.

The fear of sectarianism did not prevent the authors of the Heidelberg Catechism (1563) to include a question on the priesthood of believers. Question 32 of the Heidelberg Catechism seems to be a very considered response to the Anabaptist position. Reading Ursinus' (2004:333-340) lectures on the Heidelberg Catechism, ${ }^{2}$ we find a profound exposition of what it means to be a Christian, a disciple of Christ, to be anointed as priest, prophet and king.

In Question 32 the Heidelberg Catechism asks:

'Q. Why are you called a Christian?

A. Because I am a member of Christ by faith and thus share in His anointing, so that I may as prophet confess His Name, as priest present myself a living sacrifice of thankfulness to Him and as king fight with a free and good conscience against sin and the devil in this life, and hereafter reign with Him eternally over all creatures'. ${ }^{3}$

In the German and Latin texts of the Heidelberg Catechism the terminology as we use it ('office' or 'priesthood') does not

2.A digital copy of Ursinus Commentary on the Heidelberg Catechism is to be found at http://www.rcus.org/wp-content/uploads/2013/09/UrsinusZ_HC-Commentary-17NEW-HC.pdf.

3.See http://gksa.org.za/pdf/Eng\%20documents/heidelberg\%20catechism.pdf. 
appear (see text in Bakhuizen van den Brink 1940:162-163). Rather, the Catechism simply says that Christ and the Christian had been called and anointed (gesalbet/unctus sit) by the Holy Spirit to be prophet, priest and king. According to the Catechism, being anointed means:

- as prophet I am called to witness;

- as priest I am called to give myself as a living sacrifice (danckopffer/gratitudinis hostiam) to God;

- as king I am called to conquer in freedom and good conscience all evil.

This formulation is still of fundamental importance to our understanding of what it means to be the church of Christ in the 21st century. The origin of the threefold office of the Christian as articulated by the Heidelberg Catechism is to be found in the threefold office (munus triplex) of Christ as the anointed prophet, priest and king. Traditionally, the outpouring of the Holy Spirit on Jesus at his baptism is regarded as the moment of the public announcement and anointment of Jesus as Christ.

Similarly, the outpouring of the Holy Spirit on the church (Ac 2) is regarded as the anointment of all believers and the church collectively to the offices of priest, prophet and king.

The Synod of Dort (1618-1619), in the compilation of the Church Order, deemed it unnecessary to say anything about the priesthood of all believers. In fact, $80 \%$ of the articles of the Church Order pertains to the calling and functioning of the ministers, elders, deacons, doctors and assemblies. Ordinary members of the church are mentioned only in terms of discipline (exercised over them by the clergy and consistory) and their responsibility to attend worship and sacraments. Church members are regarded as those who must be 'comforted' by those called to ecclesial office.

It is also clear that the Synod of Dort had a somewhat elitist understanding of ministry. Only those who are educated and studied are suited and qualified to be called to ministry. This is especially clear in articles 8 and 9 of the Church Order:

8. No schoolmasters, artisans or others who have not followed the prescribed course of study for the ministry shall be admitted to the ministry, unless there is assurance of their singular gifts, godliness, humility, modesty, common sense, and discretion, together with gifts of public speaking. When such persons present themselves for the ministry, the classis shall (if the synod approves) first examine them, and after the classis by the examination finds them acceptable, it shall allow them to exhort for a time, and then further deal with them as it judges shall be edifying

9. Novices, priests, monks and those who leave any sect shall not be admitted to the ministry except with great care and caution after they have also first been tested for a certain time.

In the following years and centuries, formal theological education became an undisputed prerequisite for ordination and ministry in reformed churches. Church members were excluded from formal ministry, especially ministering of sacraments. The role of 'ordinary' church members was limited to the spiritual formation of children, maintaining a Christian household and attending Sunday service. In closely knit communities, mutual support of fellow Christians was expected and almost mandatory.

For many, the local minister became the epitome of learning and as a result the only one qualified to proclaim the gospel of Jesus Christ.

The period after the Second World War was a time marked by a growing sense of ecclesial and spiritual crisis. This revitalised the interest in ecclesiology (Kärkkäinen 2002:7-9), including the role and calling of church members. Furthermore, in the post-war ecumenical movement, the nature and mission of the church became a dominant discourse, including references to the priesthood of all believers. It is in this post-war period that Van Ruler and Kraemer published books with the titles 'Het vergeten ambt der kerk' (Kraemer) and 'Bijzonder en algemeen ambt' (Van Ruler).

Van Ruler (1952:42) was of the opinion that theologians who speak so easily of the 'office of the Christian' (ambt der gelovigen) often do so without giving proper attention to the relevant issues. One concern he raises is the question whether the term 'office' could imply an institutionalised and formal function, rather than something which flows from the community in and through the Holy Spirit. As a result, Van Ruler often speaks of 'the priesthood of all believers', but in a generic manner, including the prophetic and kingly calling. Van Ruler seems a little ambivalent in terms of 'the threefold office of the Christian' or 'the priesthood of all believers'. Van Ruler (1952:7) even points out that 'priesthood of all believers' and the 'threefold office of the Christian' could be regarded as synonyms.

Van Ruler follows Bouwman in using the term 'office', but if we read Bouwman's Gereformeerd Kerkrecht, which first appeared in 1928, we see that Bouwman consistently uses the term 'calling' instead of 'office' (Bouwman 1970:330). Only at the end of the discussion, he comes to the conclusion that we might 'even call this calling an office', and then continues to speak of a 'calling' as priest, prophet and king. The purpose of this calling is to serve and glorify God. It is also remarkable that Van Ruler (p. 39), after an extensive discussion, then continues to speak of the 'priesthood of all believers'.

Kraemer's approach is quite different. He delivered a series of lectures at Cambridge University during February 1958 on 'A Theology of the Laity' (Kraemer 1960:7). He placed these lectures within the field of congregational studies, in Dutch 'gemeenteopbouw'. Kraemer addressed this issue in the context of the crises churches experienced after the Second World War. Kraemer (1947:24) articulated this sense of crisis in his earlier and very influential publication 'The Christian message in a non-Christian world', stating that the church had never been free of crisis and will always remain ecclesia militans. The church always remains the 
pilgrim church, always facing threats from within and without. Kraemer, following Karl Barth, was convinced that the discrepancy between what the church is and how it manifests empirically is its greatest challenge. One aspect of the modern ecclesial crisis is the disappearance of the priesthood of believers; thus, a 'theology of the laity' is of utmost importance (Kraemer 1960:9). Kraemer (p. 10) is convinced that the neglect of church members (or priesthood of all believers) has its origins in a very limited ecclesiology.

Kraemer refers to the large number of publications that emphasise the responsibility of the congregant/church member, but at the same time the lack of a proper theological understanding of the issues at hand. He laments the fact that these publications almost exclusively attend to some practical issues, without systematic theological reflection. The one exception (in that time) was the work that had been carried out in Roman Catholic theology by Yves M.J. Congar (Kraemer 1960:10-11). Congar made an extensive analysis of the Corpus Iuris Canonici and came to the conclusion that it was too much about the official hierarchy and too little about church members. Sixty years after Kraemer's lectures at Cambridge University, reformed ecclesiology and church polity are still limited in terms of the priesthood of all believers.

Kraemer (1960:90-92) is very critical of the terminology used in a theology of the laity. He was of the opinion that the 'priesthood of believers' is not adequate to express the fullness of a 'theology of the laity'. He points out that exactly because the priesthood of believers was so neglected in both the Roman Catholic and reformed traditions, and because it is limited in scope and carries so much baggage with it, one should rather opt for a 'theology of the laity', which is a broader and more inclusive term. Kraemer's criticism of the limited use of the term 'general priesthood' in reformed theology is mainly based on the fact that the reformers used it to oppose the Roman Catholic understanding of the sacramental ordination and the misuse of power by the Roman clergy. It had the character of protest and democratisation - another reason why it received so little attention later on. On the other hand, one could argue that Kraemer's use of the term 'laity' is problematic. In the Dutch translation (Kraemer 1960), it is much better where he used the term 'gemeentelid' as a translation for 'laity'.

In Kraemer's chapter on a 'theologie van het gemeentelid' (Kraemer 1960:122-157), he places the role of the church member firmly within a theology of mission (missio Dei). It is not the offices of a minister, elder or deacon, which are fundamental to the existence and mission of the church, but rather the office of the 'common church member'. On the other hand, Kraemer's use of the term 'office' could also be criticised, for it carries with it a strong sense of ecclesial institutionalism that does not facilitate the missional role of church members.

\section{Priesthood of believers in the Church Order of the Nederduitsch Hervormde Kerk van Afrika}

We now turn to a more recent example of a church that intentionally included the priesthood of believers in a church order as part of a process of transformation and reformation.

The NHKA is a South African church with roots in the Dutch Reformed tradition. It could be regarded as a church in transition, as probably all South African churches. The changing sociopolitical context of South Africa, as well as rapid change within the church (such as a severe decline in the number of church members), necessitates change in ecclesial praxis and ministry. Since 1990, it became clear that these changes could not be superficial or cosmetic, but should be part and parcel of a fundamental shift in ecclesiology. Substantial and lasting transformation could only be achieved through systemic change, if the system story changes. It became clear that if the church is to reform, a shift in ecclesiology is required.

One of the reasons for this is the fact that church polity and church orders are based on ecclesiology, on our understanding of what the church is and should be (Koffeman 2009:16-21). The way we understand the church defines our church polity, which in turn influences the congregational praxis and ministry.

Initially, it was not clear what such a shift in ecclesiology would entail. The growing prominence of missional ecclesiology within South African reformed churches had some influence in the NHKA, but it needed further development and some sense of its practical implications. The process of transformation started out with the approval and implementation of new liturgical formularies, greater liturgical diversity, a new hymnbook, new mission strategies, extensive ecumenical collaboration (including theological education at the University of Pretoria) and models of ministry adapted to smaller congregations. As the process of transformation continued, the rallying cry of ecclesia semper reformanda played an important role. It made it possible to understand that tradition could be reformed without losing the essential spirit and ethos of that tradition. During the 68th General Assembly (2007), the continuing reformation of the church was formulated as a movement away from:

- self-centredness to God-centredness

- the congregation to the kingdom of God

- civil religion to genuine Christian faith

- linear thinking to systemic thinking

- institutional culture to a ministry-based culture

- programmes and actions to people and relationships

- members who are consumers to members who are co-workers in ministry (the priesthood of believers)

- a 'maintenance' model of church to a missional lifestyle.

Flowing from this, the General Assembly passed a resolution which asked for a complete revision of the Church Order 
with a strong emphasis on the missional calling of the NHKA, as well as the responsibilities and calling of church members. This in itself was quite remarkable, because just 10 years earlier (1997) the General Assembly approved a completely new Church Order, after 14 years of preparation (1983-1997).

In terms of this contribution, it must be noted that the 1997 Church Order barely mentions any responsibilities of church members and accepts attending catechesis and Sunday service. The 1997 Church Order was a classic example of a reformed church order, with the emphasis on the offices of minister, elder and deacon, as well as the assemblies of the offices (a presbyterial-synodal system of church governance). The 1997 Church Order permeated with reformed ecclesiology, to be more precise, the three notae ecclesiae as articulated in the Belgic Confession. In terms of ministry, the focus was entirely on the ordained minister's responsibilities in terms of preaching and ministering sacraments and the elder's responsibility in terms of discipline.

The 71st General Assembly of the NHKA (2016) had as point of departure Resolution 1, which articulated an ecclesiology for the NHKA at the start of the 21st century under the heading 'Kerkwees in die toekoms', which could be translated as 'Being church in the future'. Resolution I (in summary) addressed the nature and mission of the church under the following points:

- The nature of the church is not determined by the challenges of our time, but by the nature of God.

- The church is an eschatological community, living between the first and second coming of the Lord Jesus Christ.

- The church is creatura Verbi, it exists in the Word that became flesh and through the proclamation of the living Word.

- The church lives organically as the people of God, the household of the Father, the body of Christ and the temple of the Holy Spirit.

- The NHKA is a visible manifestation of the one, holy and universal church. The church lives in community (koinonia) with God and all people.

- The church is called to proclaim the gospel to the world. The church is missional. In other words, mission is not just one activity amongst many, rather the church is by its very nature missional, corresponding to the nature of God (missio Dei).

- Diversity in unity is important, both in ministry and liturgy.

Against the backdrop of Resolution 1 the revised Church Order was submitted to the General Assembly and approved unanimously. The priesthood of believers received specific attention in articles 4 (NHKA 2016:66), 6 (pp. 74-75) and 7 (pp. 77-79) of the revised Church Order.

In Ordinance 4, the priesthood of believers is mentioned explicitly in relation to the female members of the NHKA, who, on the basis of the priesthood of believers, form branches of the women's association (Nederduitsch Hervormde Sustervereniging) in the various congregations to fulfil their calling.

In Ordinance 6, the priesthood of believers is mentioned expressis verbis in relation to Christian formation and education. The article states that with the purpose of fulfilling their responsibilities in terms of the priesthood of believers, church members are educated in the following ways:

- preparation for baptism and/or Communion

- preparation for confirmation through catechesis

- preparation for marriage

- formation of elders and deacons for official duties

- adult catechesis

- church publications

- spiritual formation of young people in terms of discipleship

- family guidance in terms of personal devotions, prayer and Bible study.

In Ordinance 7 , the church as a missional community is addressed. In Ordinance 7.1.1. (p. 77), it is stated that the congregation is called to 'live as a missional community, as a witness to God's love with the purpose to teach people to live as disciples of Jesus Christ'. In Ordinance 7, specific attention is given to the responsibility of all church members to proclaim the gospel of Jesus Christ in various ways in the world and everyday life.

In comparison with the 1997 Church Order, the 2016 revised Church Order reflects a fundamental shift in ecclesiology, which includes the priesthood of believers and the responsibility of church members to live as disciples of Jesus Christ. This ecclesiology was presented to the church in visual form and with a very simple motto: Being church in the footsteps of Christ. Many congregations are currently using this as their logo and vision, although a certain uneasiness is still evident. This has much to do with the question of how a missional ecclesiology relates to reformed ecclesiology, ministry and ecclesial praxis.

\section{Concluding remarks}

Going forward, it seems to me important to clarify terminology if the priesthood of believers is to receive its proper attention. One obstacle is the use of the term 'office of the believer' or when the priesthood of believers is regarded as an 'office' in the sense of a priest or a minister, even contrary to ordained ministry with the danger of sectarian sentiments. Two things could assist us in avoiding some of the pitfalls surrounding the priesthood of believers:

- In the New Testament, the term 'office' is never used or intended in connection with the priesthood of all believers. When the New Testament (e.g. 1 Pt 2:5) speaks of the holy priesthood, the whole people of God is implied who are responsible to serve God through spiritual gifts. The priesthood of believers is a general term and not an indication of a specific office. 
- The Heidelberg Catechism teaches us that Jesus was anointed as the Christ, as priest, prophet and king. It is remarkable that the Heidelberg Catechism does not use the term 'office' in relation to Christ's or our own anointment. All Christians, who were grafted into Christ, were anointed by the Holy Spirit to serve God as priests, prophets and kings. If the priesthood of believers is to find wider practical application within reformed churches, especially in terms of a missional ecclesiology, Question 32 of the Heidelberg Catechism could serve as guide. I am of the opinion that Question 32 should be articulated more precisely in reformed church orders, including the Church Order of the NHKA. If the priesthood of believers would be articulated in terms of Question 32, it should reflect the intention of the Heidelberg Catechism by not allowing it to be institutionalised but by maintaining the aspect of anointment and calling. The priesthood of believers should be understood as including the prophetic and kingly calling of all believers.

With all this in mind, I am of the opinion that we should not think of the priesthood of believers in terms of an office (officium) but rather as service (ministerium). This service is performed in obedience to God and unity with Christ, by those who were baptised into his death and resurrection (Rm 6), were anointed by and with the Holy Spirit, and as a result share in his priestly, kingly and prophetic ministry.

Hans-Martin Barth (1990:103) states categorically: 'The Protestant Church is the church of the universal priesthood or it is nothing' (own translation). Going forward, the role of ordained ministry will in all probability become limited, and the priesthood of believers will become increasingly important. How and on what grounds the priesthood of believers will be included in church orders and ecclesial praxis is one of the challenges facing church polity, or for that matter, a practical ecclesiology.

\section{Acknowledgements Competing interests}

The author declares that no competing interests exist.

\section{Author's contributions}

I declare that I am the sole author of this research article.

\section{Ethical consideration}

This article followed all ethical standards for a research without direct contact with human or animal subjects.

\section{Funding information}

This research received no specific grant from any funding agency, in the public, commercial or non-profit sectors.

\section{Data availability statement}

Data sharing is not applicable as no new data were created or analysed.

\section{Disclaimer}

The views and opinions expressed in this article are those of the author and do not necessarily reflect the official policy or position of any affiliated agency.

\section{References}

Aguilan, V., 2015, The priesthood of all believers: Ecclesiological and political implications today, paper uploaded 09 March 2016, viewed 15 June 2018, from https://www.researchgate.net/publication/297707832_The_Priesthood_of_all_ Believers_Ecclesiological_and_Political_Implications_Today.

Althaus, P. \& Schultz, R.C., 1966, The theology of Martin Luther, Fortress Press, Philadelphia, PA

Bakhuizen van den Brink, J.N., 1940, De Nederlandsche Belijdenisgeschriften, Uitgeversmaatschappij Holland, Amsterdam.

Barth, H-M., 1990, Einander Priester sein: Allgemeines Priestertum in ökumenischer perspektive, Vandenhoeck \& Ruprecht, Göttingen.

Dreyer, W.A., 2016, 'Praktiese ekklesiologie - Kerkwees in die 21ste eeu', HTS Teologiese Studies/Theological Studies $72(5$ suppl. 10), a4375. https://doi. org/10.4102/hts.v72i5.4375

Goold, G.P. \& Lake, K., 1975, The apostolic fathers vol. I \& 2, G.P. Goold (ed.), transl. K. Lake, Harvard University Press, Cambridge, MA.

Jones, R.M., 1918, 'The Anabaptists and minor sects in the reformation', Harvard Theological Review XI(3), 223-246. https://doi.org/10.1017/S0017816000011731 Kärkkäinen, V.-M., 2002, An introduction to ecclesiology, IVP Academic, Downers Grove, IL.

Koffeman, L.J., 2009, Het goed recht van de kerk: Een theologische inleiding op het kerkrecht, Kok, Kampen.

Kraemer, H., 1947, The Christian message in a non-Christian world, Edinburgh House Press, London.

Kraemer, H., 1960, Het vergeten ambt in de kerk, Boekencentrum N.V.,'s-Gravenhage, Gravenhage.

Luther, M., [1520] 1966, 'To the Christian nobility of the German nation', in J. Atkinson (ed.) and transl. C.M. Jacobs, Luther's works: The Christian in society I, pp. 126-134, Fortress Press, Philadelphia, PA.

Mannion, G. \& Mudge, L.S. (reds.), 2010, The Routledge companion to the Christian Church, Routledge, New York, NY.

Moriarty, W., 2012, '1 Clement's view of ministerial appointments in the early Church', Vigiliae Christianae 66(2), 115-138. https://doi.org/10.1163/157007211X586142

NHKA, 2016, Kerkorde van die Nederduitsch Hervormde Kerk van Afrika, Kerkargief, Pretoria.

Niesel, W., 1957, Die Theologie Calvins, EVZ-Verlag, Zurich.

Pont, A.D., 1989, 'Die priesterskap van die gelowiges soos Calvyn dit gesien het', HTS Theological Studies 45(2), 451-460. https://doi.org/10.4102/hts.v45i2.2288

Roldán, A.F., 2004, 'The priesthood of believersand integral mission', in T. Yamamori \& C.R. Padilla (eds.), transl. Brian Condignly from the Spanish, La ogles local como agent de transformacion, The local church, agent of transformation: An ecclesiology for integral missions, pp. 151-177, Editions Kairos, Buenos Aires.

Stark, R., 1996, The rise of Christianity: How the obscure, marginal Jesus movement became the dominant religious force in the Western World in a few centuries, Harper Collins, San Francisco, CA.

Ursinus, Z., 2004, The Commentary of Dr. Zacharias Ursinus on the Heidelberg Catechism, transl. G.W. Williard and edited for digital publication by E.D. Bristley for the Synod of the Reformed Church in the United States, viewed 02 April 2020, from http://www.rcus.org/wp-content/uploads/2013/09/UrsinusZ_HCCommentary-17-NEW-HC.pdf.

Van Aarde, A.G., 1995, 'Die historiese Jesus en die kerk', HTS Teologiese Studies 51(3), 623-644.

Van Aarde, TA, 2017, 'The missional church structure and the priesthood of believers (Ephesians 4:7-16) in the light of the inward and outward function of the church' Verbum et Ecclesia 38(1), a1709. https://doi.org/10.4102/ve.v38i1.1709

Van Ruler, A.A., 1952, Bijzonder en algemeen ambt, G.F. Callenbach N.V. Uitgever, Nijkerk.

Van't Spijker, W. (ed.), 1990, De Kerk: Wezen, weg en werk van die kerk naar reformatorische opvatting, De Groot Goudriaan, Kampen.

Voss, J.H., 2013, 'The priesthood of believers and the missio Dei: A canonical Catholic and contextual perspective', PhD dissertation (Systematic Theology), submitted to Wheaton College, IL. 